\title{
Synthesis of Anthranilic Acid and Phthalic Anhydride Ligand and their Metal Complexes
}

\author{
Saleem Raza1, Yousaf Iqbal', Iqbal Hussian², Muslim Raza1, Syed Uzair Ali Shah³, Ajmal Khan³, Raheela Taj' and Abdur Rauf* \\ 1 Institute of Chemical Sciences, University of Peshawar, Peshawar, Pakistan \\ ${ }^{2}$ Department of Chemistry, Kohat University of Science \& Technology, Kohat, Pakistan \\ ${ }^{3}$ Hussain Ebrahim Jamal Research Institute of Chemistry, International Center for Chemical and Biological Sciences, University of Karachi, Pakistan
}

\begin{abstract}
Anthranilic acid and phthalic anhydrides have the ability make ligand complexes with the metal ions, which were found to be important for various applications. In the present study, the attempts were carried to form complexes of anthranilic acid and phthalic anhydride ligand with Lead acetate $\left(\mathrm{Pb}\left(\mathrm{CH}_{3} \mathrm{COO}\right)_{2}\right)$, Cobalt chloride $\left(\mathrm{Cocl}_{2}\right.$. $\left.6 \mathrm{H}_{2} \mathrm{O}\right)$, Cadmium sulfate $\left(\mathrm{CdSO} \cdot \mathrm{H}_{2} \mathrm{O}\right)$, Copper chloride $\left(\mathrm{CuCl}_{2} \cdot 2 \mathrm{H}_{2} 0\right)$, and Tin chloride of well-defined stoichiometry in the range of $\mathrm{pH} 6$ and 8 in variable ratios. The IR spectra of complexes were interpreted and compared with data in the literature. Furthermore the resultant complexes were evaluated for the anti-bacterial potential.
\end{abstract}

Keywords: Anthranilic acid; Phthalic Anhydride; DMSO; Methanol; Chloroform; $\mathrm{NaOH}$

\section{Introduction}

The compounds containing the complex ion or complex molecule in which central metal atom or ion is surrounded by a number of oppositely charged ions or molecules are known as co-ordination compounds [1], complex compound or simply complex. Coordination basically refers to the "coordinate covalent bonds" (dipolar bonds) between the ligands and the central atom in 1914, when first coordination complex, hexol was resolved by Werner [2].

Among the ligands, anthranilic acid $\left(\mathrm{C}_{6} \mathrm{H}_{4}\left(\mathrm{NH}_{2}\right) \mathrm{COOH}\right)$ is one of the best compound used by Carl Julius Fritzche (1808-1871) in the laboratory in St. Peterburg by degrading ancient dye indigo [3]. It is a white solid amino acid in pure form whereas commercially available in yellow form. Its molecule consists of a benzene ring with two adjacent functional groups, a carboxylic acid and an amine [3]. Several investigators worked on the synthesis of anthranilic acid dyes in the various conditions which have shown significant biological activity especially against bacteria $S$. aureus and E. coli and [4]. The mixed ligand complexes of $\mathrm{Co}$ (II), $\mathrm{Ni}$ (II), $\mathrm{Cu}$ (II) and $\mathrm{Zn}$ (II) with anthranillic acid and tributylphosphine have shown profound activity against Staphylococcus, Klebsiella SPP. and Bacillas [5]. Furthermore, the rhodium complexes with (N-phenyl) anthranillic acid ligands are used as catalysts for the hydrogenation [6]. Several other mixed ligands complexes with anthranilic acid were reported to have antifungal and antibacterial potential [7].

Phthalic anhydride $\left(\mathrm{C}_{6} \mathrm{H}_{4}(\mathrm{CO})_{2} \mathrm{O}\right)$ is colorless solid and an important industrial chemical, especially for the large-scale production of plasticizers for plastics [8]. The phthallic anhydride ring opening reaction by alcohols when carried out in presence of different metal salts, results in the formation of metal carboxylate complexes [9]. The phathalate esters are also produced via phthallic anhydride ring opening reaction used for chiral separation of optically active alcohols and amines [10], however in the presence of amino acids such as glycine, the reactions of phthalic anhydrides help in preparing $\mathrm{N}$-phthaloylglycinato complexes of transition metals [11]. The metal complexes of amino acids with phthalic anhydride revealed higher antimicrobial activity $P$. aerugenosa, E. coli, S. aureus and C. albicans than their respective ligands [12].
In the present study, we synthesized the complexes of anthranilic acid and pthalic anhydride ligands with cadmium $(\mathrm{Cd})$, copper $(\mathrm{Cu})$, of cobalt $(\mathrm{Co})$, lead $(\mathrm{Pb})$ and Tin $(\mathrm{Sn})$, however special emphasis has been given to the first ever complexes of $\mathrm{Co}$ and lead $\mathrm{Pb}$. For the structural elucidation of these complexes IR spectral analysis was used. The antibacterial potential of the complexes was assessed against Bacillus subtilis, Staphylococcus aureus, Pseudomonas aeruginosa, MethicillinResistant Staphylococcus Aureus (MRSA).

\section{Material and Methods}

All chemicals and the reagents used in our study were reagent grade (Table 1). The solvents were redistilled by standard techniques before

\begin{tabular}{|l|c|c|c|}
\hline S.NO. & Chemical Name & Chemical Formula & Mol. weight \\
\hline 1. & Salts & & \\
\hline 2. & Lead acetate & $\mathrm{Pb}\left(\mathrm{CH}_{3} \mathrm{COO}\right)_{2}$ & 361.33 \\
\hline 3. & Cobalt chloride & $\mathrm{CoCl}_{2} \cdot 6 \mathrm{H}_{2} \mathrm{O}$ & 237.93 \\
\hline 4. & Cadmium sulfate & $\mathrm{CdSO}_{4} \cdot \mathrm{H}_{2} \mathrm{O}$ & 226.490 \\
\hline 5. & Copper chloride & $\mathrm{CuCl}_{2} \cdot 2 \mathrm{H}_{2} \mathrm{O}$ & 170.48 \\
\hline & Tin chloride & $\mathrm{Sncl}_{2} \cdot 2 \mathrm{H}_{2} \mathrm{O}$ & 225.63 \\
\hline 1. & Solvent & & \\
\hline 2. & Distal Water & $\mathrm{H}_{2} \mathrm{O}$ & 18 \\
\hline 3. & Methanol & $\mathrm{CH}_{3} \mathrm{OH}$ & 32 \\
\hline & DMSO & $\mathrm{C}_{2} \mathrm{H}_{6} \mathrm{OS}$ & 78 \\
\hline 1. & Chemicals & & 137.14 \\
\hline 2. & Anthranilic acid & $\mathrm{C}_{7} \mathrm{H}_{7} \mathrm{NO}_{2}$ & 148.12 \\
\hline 3. & Pthalic anhydride & $\mathrm{C}_{8} \mathrm{H}_{4} \mathrm{O}_{3}$ & 40 \\
\hline & Sodium hydroxide & $\mathrm{NaOH}^{2}$ & \\
\hline
\end{tabular}

Table 1: The list of chemicals, reagents and solvents used in the study.

*Corresponding author: Abdur Rauf, Institute of Chemical Sciences, University of Peshawar, Peshawar, Pakistan, Tel: 923469488944; E-mail: abdurraufphd@upesh.edu.pk or mashaljcs@yahoo.com

Received September 21, 2013; Accepted November 18, 2013; Published November 21, 2013

Citation: Raza S, Iqbal Y, Hussian I, Raza M, Shah SUA, et al. (2013) Synthesis of Anthranilic Acid and Phthalic Anhydride Ligand and their Metal Complexes. Biochem Anal Biochem 2: 143. doi: 10.4172/2161-1009.1000143

Copyright: () 2013 Raza S, et al. This is an open-access article distributed under the terms of the Creative Commons Attribution License, which permits unrestricted use, distribution, and reproduction in any medium, provided the original author and source are credited. 
Citation: Raza S, Iqbal Y, Hussian I, Raza M, Shah SUA, et al. (2013) Synthesis of Anthranilic Acid and Phthalic Anhydride Ligand and their Metal Complexes. Biochem Anal Biochem 2: 143. doi: 10.4172/2161-1009.1000143

use. All the glass wares were carefully washed with distilled water and methanol and then dried in the oven at $100^{\circ} \mathrm{C}$ before the use.

\section{Experimental}

Synthesis of ligand: Anthranilic acid (1.1g) was taken in erlenmeyer flask $25 \mathrm{~cm}^{3}$ with pthalic anhydride $(1 \mathrm{~g})$ and heated in paraffin oil at $130^{\circ} \mathrm{C}-150^{\circ} \mathrm{C}$. Then poured into a beaker containing distilled water, allowed to cool, filtered and dried it in oven at $60^{\circ} \mathrm{C}$. Recrystallization was carried out using ethanol as solvent to yield $1.2 \mathrm{~g}$ of product [13]. Same types of worked has also been reported in literature [14] using vanillin, 4-aminoantipyrine and 1-phenyl 2, 3 dimethyl-4-aminopyrozol-5-one.<smiles>O=C1CC(=O)c2ccccc21</smiles><smiles>Nc1ccccc1C(=O)O</smiles>

Pthalic anhydride

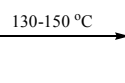

Antranilic aci

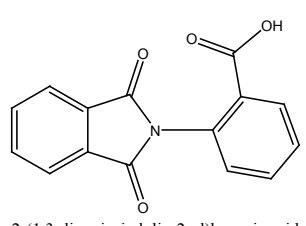

2-(1,3-dioxoisoindolin-2-yl)benzoic acid

\section{Preparation of reagents}

$0.5 \mathrm{M} \mathrm{NaOH}$ is prepared by mixing $0.5 \mathrm{gm}$ of $\mathrm{NaOH}$ in $25 \mathrm{~cm}^{3}$ of water.

Preparation of Metallic Solution: Metals solution of Lead acetate $\left(\mathrm{Pb}\left(\mathrm{CH}_{3} \mathrm{COO}\right)_{2}\right)$, Cobalt chloride $\left(\mathrm{Cocl}_{2} \cdot 6 \mathrm{H}_{2} \mathrm{O}\right)$, Cadmium sulfate $\left(\mathrm{CdSO}_{4} \cdot \mathrm{H}_{2} \mathrm{O}\right)$, Copper chloride $\left(\mathrm{CuCl}_{2} \cdot 2 \mathrm{H}_{2} 0\right)$, and Tin chloride ( $\mathrm{Sncl}_{2} .2 \mathrm{H}_{2} \mathrm{O}$ ), by weighing accurately $2-3 \mathrm{~g}$ and $10 \mathrm{~cm}^{3}$ methanol was added and then stirred.

Complexation of ligand with metal: The formation of complex of ligand with essential and trace elements involve the reaction of ligand with metal halide in methanol $20 \mathrm{~cm}^{3}$. The complex formation involved stirring the reaction mixture containing ligand and metal salts for 30 40 minutes at room temperature. The reaction mixture was filtered, washed with water and methanol and dried at room temperature to yield the product. The general structure of these complexes is shown in the Figure 1.

Synthesis of ligand-lead acetate complex: Ligand (1.5 g) was dissolved in DMSO $(10 \mathrm{ml})$ and Lead acetate $(2.12 \mathrm{~g})$ dissolved in DMSO $(10 \mathrm{ml})$ was added slowly to the solution. The mixture was stirred for $30 \mathrm{~min}$ while the $\mathrm{pH}$ was adjusted at 8.0 by $0.5 \mathrm{M} \mathrm{NaOH}$ solution. The reaction mixture was then filtered, recrystallized to yield the product $(1.01 \mathrm{~g})$, the percent yield was found to be $27.9 \%$ (Table 2).

Synthesis of ligand-cobalt complex: Ligand $(1.5 \mathrm{~g})$ was dissolved in DMSO $(10 \mathrm{ml})$ and the solution of cobalt chloride $(1.33 \mathrm{~g}$ dissolved in $10 \mathrm{ml}$ of DMSO) was added slowly to the solution. The mixture was stirred for 30 minute while the $\mathrm{pH}$ was adjusted at 8.0 by $0.5 \mathrm{M} \mathrm{NaOH}$ solution. The reaction mixture was then filtered, recrystallized to yield the product $(0.4 \mathrm{~g})$ the percent yield was found to be $14.13 \%$ (Table 2$)$.

Synthesis of ligand-cadmium complex: Ligand (1.5 g) was dissolved in DMSO $(10 \mathrm{ml})$ and cadmium sulphate solution $(4.3 \mathrm{~g}$ dissolved in $10 \mathrm{ml}$ of DMSO) was added slowly to the solution. The mixture was stirred for 30 minute and the $\mathrm{pH}$ was adjusted at 8.0 by using $0.5 \mathrm{M} \mathrm{NaOH}$ solution. The reaction mixture was then filtered, recrystallized to yield the product $(0.25 \mathrm{~g})$ and the percent yield was found to be $4.31 \%$ (Table 2).

Synthesis of ligand- copper complex: The ligand solution was prepared by dissolving ligand $(1.5 \mathrm{~g})$ in $10 \mathrm{ml}$ of DMSO and copper chloride solution ( $0.95 \mathrm{~g}$ dissolved in $20 \mathrm{ml}$ of DMSO) was added slowly to the solution. The mixture was stirred for 30 minute and the $\mathrm{pH}$ was adjusted at 8.0 by $0.5 \mathrm{M} \mathrm{NaOH}$. The reaction mixture was then filtered, recrystallized to yield the product $(0.4 \mathrm{~g})$, the percent yield was found to be $16.32 \%$ (Table 2)

Synthesis of ligand-tin complex: The ligand solution was prepared by dissolving ligand $(1.5 \mathrm{~g})$ in $10 \mathrm{ml}$ of DMSO and Tin chloride solution ( $1.2 \mathrm{~g}$ dissolved in $10 \mathrm{ml}$ DMSO) was added slowly to the solution. The mixture was stirred for 30 minute and $\mathrm{pH}$ was adjusted at 8.0 by $0.5 \mathrm{M}$ $\mathrm{NaOH}$. The reaction mixture was then filtered, recrystallized to yield the product $(0.5 \mathrm{~g})$, the percent yield was found to be $18.51 \%$ (Table 2 ).

\section{Antimicrobial activity}

The antibacterial sensitivity was performed using modified agar well diffusion method to test the antibacterial potential of the compounds. The Mueller-Hinton Agar (MHA) was used as medium. The cultures were taken in triplicates at incubation temperature of $37^{\circ} \mathrm{C}$ for 24 to 72 hours. The broth culture $(0.6 \mathrm{ml})$ of the test organism was placed in a sterile petri-dish and $20 \mathrm{ml}$ of the sterile molten MHA was added to each petri-dish. Holes were bored in to the medium using $0.2 \mathrm{ml}$ of the compound. The reference drug, streptomycin was used as standard antimicrobial agent in concentration of $2 \mathrm{mg} / \mathrm{ml}$. Inoculation was done for 1 hour to make possible the diffusion of the antimicrobial agent into the medium. Incubation was done at $37^{\circ} \mathrm{C}$ for $24 \mathrm{~h}$ and the diameters of the zone of inhibition of microbial growth were measured in the plate in $\mathrm{mm}[15,16]$.

\section{Results and Discussion}

The IR spectra of ligands and ligand complexes with $\mathrm{Co}, \mathrm{Pb}$, $\mathrm{Cd}, \mathrm{Cu}, \mathrm{Sn}$ are demonstrated in Table 3. The band of carboxylic $(\mathrm{COOH})$ appeared at $3119 \mathrm{~cm}^{-1}$ in the spectrum of ligands however it was observed in the range of $3444 \mathrm{~cm}^{-1}, 3455 \mathrm{~cm}^{-1}, 3469 \mathrm{~cm}^{-1}, 3456 \mathrm{~cm}$ ${ }^{1}, 3456 \mathrm{~cm}^{-1}$ in Lead $(\mathrm{Pb})$, Cobalt $(\mathrm{Co})$, Cadmium $(\mathrm{Cd})$, Copper $(\mathrm{Cu})$ and Tin (Sn) complexes respectively, which are in co-relation with previous studies [17]. The imide (CONH) band of the ligands appeared at $1723 \mathrm{~cm}^{-1}$ however the complexes show this band at around 1619 $1620 \mathrm{~cm}^{-1}$ range. This observation indicated that coordination of the

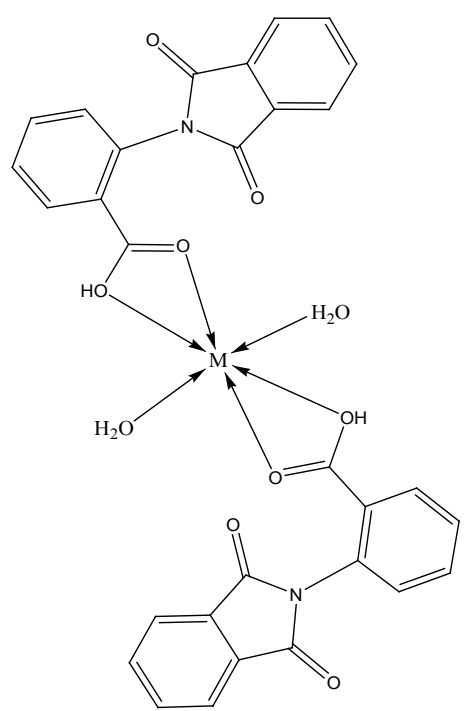

Figure 1: General structure of complexes. 
Citation: Raza S, Iqbal Y, Hussian I, Raza M, Shah SUA, et al. (2013) Synthesis of Anthranilic Acid and Phthalic Anhydride Ligand and their Metal Complexes. Biochem Anal Biochem 2: 143. doi: 10.4172/2161-1009.1000143

Page 3 of 4

\begin{tabular}{|c|c|c|c|c|c|c|}
\hline S.No & Ligand & Metals & Ratio & DMSO (ml) & Reaction Time (Min.) & Product yield (\%) \\
\hline 1 & Anthranilic Acid + Pthalic Anhydrides & $\mathrm{Pb}\left(\mathrm{CH}_{3} \mathrm{COO}\right)_{2}$ & $1.5: 2.12$ & 20 & $30-45$ & 27.9 \\
\hline 2 & Anthranilic Acid + Pthalic Anhydrides & $\mathrm{CoCl}_{2} \cdot 6 \mathrm{H}_{2} \mathrm{O}$ & $1.5: 1.33$ & 20 & $30-45$ & 14.13 \\
\hline 3 & Anthranilic Acid + Pthalic Anhydrides & $\mathrm{CdSO}_{4} \cdot \mathrm{H}_{2} \mathrm{O}$ & $1.5: 4.3$ & 20 & $30-45$ & 40.31 \\
\hline 4 & Anthranilic Acid + Pthalic Anhydrides & $\mathrm{CuCl}_{2} \cdot 2 \mathrm{H}_{2} \mathrm{O}$ & $1.5: 0.95$ & 20 & $30-45$ & 16.32 \\
\hline 5 & Anthranilic Acid + Pthalic Anhydrides & $\mathrm{Sncl}_{2} \cdot 2 \mathrm{H}_{2} \mathrm{O}$ & $1.5: 1.2$ & 20 & $30-45$ & 18.51 \\
\hline
\end{tabular}

Table 2: The ratio of reactants and percent yield in each reaction.

\begin{tabular}{|c|c|c|c|c|c|c|}
\hline COMPOUND & $(\mathrm{COOH})\left(\mathrm{cm}^{-1}\right)$ & $(\mathrm{CONH})\left(\mathrm{cm}^{-1}\right)$ & $(\mathrm{C}-\mathrm{N})\left(\mathrm{cm}^{-1}\right)$ & $(\mathrm{C}=\mathrm{C})\left(\mathrm{cm}^{-1}\right)$ & $(\mathrm{M}-\mathrm{O})\left(\mathrm{cm}^{-1}\right)$ & $(\mathrm{OH})\left(\mathrm{cm}^{-1}\right)$ \\
\hline [Ligand] & 3119 & 1723 & 1248 & 1469 & ----- & ----- \\
\hline [Pb(Ligand)] & 3444 & 1619 & 1228 & 1403 & $537-672$ & 3444 \\
\hline [Co(Ligand)] & 3455 & 1620 & 1229 & 1469 & $522-639$ & 3455 \\
\hline [Cd(Ligand)] & 3469 & 1653 & 942 & 1487 & $585-752$ & 3469 \\
\hline [Cu(Ligand)] & 3456 & 1718 & 1169 & 1465 & $535-763$ & 3456 \\
\hline [Sn(Ligand)] & 3456 & 1655 & 1216 & 1354 & 568 & 3456 \\
\hline
\end{tabular}

Where, the $\mathrm{COOH}, \mathrm{CONH}, \mathrm{C}-\mathrm{N}, \mathrm{C}=\mathrm{C}, \mathrm{M}-\mathrm{O}$ and $\mathrm{OH}$ represent carboxylic carbonyl, imide carbonyl, carbon-nitrogen single bond, carbon-carbon double bond, metal-oxygen bond and hydroxyl group respectively

Table 3: The values of the metal complexes collecteed from IR spectra.

\begin{tabular}{|c|c|c|c|c|c|c|}
\hline Microorganism & 1 & 2 & 3 & 4 & 5 & STD \\
\hline Bacillus subtilis & - & - & 13 & - & - & 20 \\
\hline Staphylococcus aureus & - & - & 10 & 11 & - & 22 \\
\hline Pseudomonas aeruginosa & - & - & 22 & - & - & 22 \\
\hline MRSA & - & - & 15 & - & - & 20 \\
\hline
\end{tabular}

Key: - = Not active; Well size: $4 \mathrm{~mm}$

S. aureus, K. pneumonia, B. subtilis, MRSA: Methicillin-resistant Staphylococcus aureus

Table 4: Antibacterial sensitivity of synthetic compounds where.

ligand occurs through the oxygen from the carboxylic carbonyl group rather than imide groups as the shift was not significant in case of imide linkage [18].

The presence of metal oxygen (M-O) stretching vibrations at carboxylic carbonyl group at $537-672 \mathrm{~cm}^{-1}, 522-639 \mathrm{~cm}^{-1}, 585-752 \mathrm{~cm}$ ${ }^{1}, 535-763 \mathrm{~cm}^{-1}, 535-763 \mathrm{~cm}^{-1}, 568 \mathrm{~cm}^{-1}$ in Lead $(\mathrm{Pb})$, Cobalt $(\mathrm{Co})$, Cadmium (Cd), Copper $(\mathrm{Cu})$, Tin $(\mathrm{Sn})$ complexes respectively for the metal complexes which was absent in ligand. Thus it suggests that coordination complexes formed by the ligand are bi-dentate. The anthranilic acid and pthalic anhydride complexes have diverse application in daily life and some of them have been found useful for human life while others are harmful. Some of their application reported from literature such as functionalization of Polyanthranilic Acid (PAA), a self-doped conducting polymer with Co (II) metal complex has been reported and used in the development of azidothymidine drug sensor [19]. The complexes synthesized in our study might have potential and should be studied in the light of these reports. Complexes of lead have been found to be Carcinogenic and have been reported in literature [20]. Dollwet and Sorenson reported the synthesis and applications of copper complexes, and found to be effective for sterilization of chest wounds and drinking water [21]. The use of tin as modifier for transition metal complexes has been extensively studied, as hydrogenation and aromatization catalysts in the process of petroleum reforming $[22,23]$.

The synthetic compounds were further evaluated for their antibacterial properties against selected bacterial strain (Bacillus subtilis, Staphylococcus aureus, Pseudomonas aemginosa, Methicillinresistant Staphylococcus aureus. The antibacterial potential of compounds is shown in Table 4. The promising effects was observed by compound 4 against Staphylococcus aureus with zone of inhibition $11 \mathrm{~mm}$, while compound 3 showed excellent activities against Bacillus subtilis, Staphylococcus aureus, Pseudomonas aemginosa, with zone of inhibition ranging from 10 to $22 \mathrm{~mm}$ at tested concentration of ( $2 \mathrm{mg}$ / $\mathrm{ml}$ ). The compound were also screening against resistance pathogen (Methicillin-resistant Staphylococcus aureus) only compound 3 exhibited significance activity against the tested strain among the entire compounds.

\section{Conclusion}

In the present study, the complexes of anthranilic acid and pthalic anhydride ligands with cadmium $(\mathrm{Cd})$, copper $(\mathrm{Cu})$, of cobalt $(\mathrm{Co})$, lead $(\mathrm{Pb})$ and Tin $(\mathrm{Sn})$ were synthesized and screened for anti-pathogenic effect. We concluded that the complex of cobalt (Co) anthranilic acid and pthalic anhydride ligands have better anti-pathogenic effect compared to the rest of three metal complexes. The cobalt complex demonstrated better activity against Pseudomonas aeruginosa than rest of tested bacterial strains. The use of such complexes might be better for treatment of bacterial infection and should be investigated further.

\section{References}

1. Cotton FA, Murillo CA, Bochmann M, Wilkinson G (1999) Advanced Inorganic Chemistry. Sixth edition 1355 .

2. Werner A (1914) Zur Kenntnis des asymmetrischen Kobaltatoms X. Ber deutsch. chem. Ges 47.

3. Sheibley FE (1943) Carl Julius Fritzsche and the discovery of anthranilic acid. J. Chem. Educ 20: 115

4. Foye WO, Lemke TC, Williams DA (1995) Principles of Medicinal Chemistry,4th Ed, BT Waverly Pvt. Ltd., New Delhi 247.

5. Taghreed HA, Khalid FA, Amer JJ, Aliea SK (2013) Synthesis, spectral and antimicrobial activity of mixed ligand complexes of $\mathrm{Co}(\mathrm{II}), \mathrm{Ni}(\mathrm{II}), \mathrm{Cu}(\mathrm{II})$ and $\mathrm{Zn}$ (II) with Anthranillic Acid and Tributylphosphine. Chem. Mater. Res 3: 126-133.

6. Ros TG, vander Lee MK, Van Dillen AJ, Geus JW, Koningsberger DC (2002) Rhodium complexes with $\mathrm{N}$-phenyl anthranilic acid ligands as catalysts for hydrogenation. J. Mol. Catal. A-Chem 186: 13-24. 
Citation: Raza S, Iqbal Y, Hussian I, Raza M, Shah SUA, et al. (2013) Synthesis of Anthranilic Acid and Phthalic Anhydride Ligand and their Metal Complexes. Biochem Anal Biochem 2: 143. doi: 10.4172/2161-1009.1000143

7. Prasad BB, Sah R (2013) A biomimicing approach to the mixed ligand complexes of bivalent transition metal. Int. J. Appl. Sci. Biotechnol 1: 16-20.

8. Peter ML, Friedrick KT, Walter E, Rudolf J, Naresh B, et al. (2007) Phthalic Acid and Derivatives in Ullmann's Encyclopedia of Industrial Chemistry, Weinheim: Wiley-VCH.

9. Deka K, Barooah N, Sarma RJ, Baruah JB (2007) Self assembled carboxylate complexes of zinc, nickel and copper, J. Mol. Struct 827: 44-49.

10. Mereyala HB, Koduru SR, Cheemalpati VN (2006) Resolution of 1-arylalkylamines with 3-O-hydrogen phthalate glucofuranose derivatives: role of steric bulk in a family of resolving agents. Tett. Asym 17: 259-267.

11. Barooah N, Sarma RJ, Batsanov AS, Baruah JB (2006) N-phthaloylglycinato complexes of cobalt, nickel, copper and zinc, Polyhedron 25: 17-24.

12. Tella AC, Oguntoye SO, Osunniran WA, Arise RO (2012) Coordination compounds of N-phthaloylglycine and $\mathrm{N}$-phthaloyltyrosine and their antimicrobial activities. Elixir Appl. Chem. 45: 7620-7623.

13. March J (1992) Advanced Organic Chemistry: Reactions, Mechanisms and Structure, 4th ed, Wiley: New York 411-413.

14. Agarwal RK, George P, Agarwal H, Chandra J (1997) Synthesis,MagnetoSpectral and Thermal Studies of Cobalt(II) and Nickel(II)Complexes of 4-[N-(4Dimethylaminobenzylidene) amino] Antipyrine. Snth. React. Inorg. Met-Org Chem 27: 251-268.
15. Uddin G, Rauf A, Qaisar M, Latif A, Ali M (2011) Preliminary phytochemical screening and antimicrobial activity of hedera helix L, Middle-East J. Scientific Res 8: 198-202.

16. Uddin G Rauf A (2012) Phytochemical screening, antimicrobial and antioxidant activities of aerial parts of Quercus robur L, Middle-East J. Med. PI Res 1: 1-4.

17. Paula Atkins PP, Julio de (2009) Elements of physical chemistry. 5th ed Oxford: Oxford UP 459.

18. Mukamel S (2000) Multidimensional femtosecond correlation spectroscopies of electronic and vibrational excitations. Annu Rev Phys Chem 51: 691-729.

19. Abbasi SA, Nipaney PC, Soni R (1989) Environmental status of cobalt and its micro determination with 7-nit.roso-8-hydroxyquinoline-5-sulfonic acid in waters, aquatic weeds and animal tissues. Analytical Letters 22: 225-235.

20. Akron (2010) The Chemical Database. The Department of Chemistry at the University of Akron.

21. Dollwet HH, Sorenson JRJ (1985) Historic uses of copper compounds in medicine. Trace Elem. Med. 2: 80-87.

22. Adams RD, Trufan E (2008) Diruthenium-tin complexes from the reaction of $\mathrm{Ph} 2 \mathrm{SnH} 2$ with $\mathrm{Ru}(\mathrm{CO}) 5$ and their reactions with bis(tri-tert-butylphosphine) platinum. Organometallics 27: 4108-4115.

23. Thomas JM, Johnson BF, Raja R, Sankar G, Midgley PA (2003) Highperformance nanocatalysts for single-step hydrogenations. Acc Chem Res 36 20-30 